Vol. 8 (1999): 285-298.

\title{
The effect of incorporation time of different crops on the residual effect on spring cereals
}

\author{
Hannu Känkänen \\ Agricultural Research Centre of Finland, Plant Production Research, FIN-31600 Jokioinen, \\ Finland, e-mail: hannu.kankanen@mtt.fi
}

Arjo Kangas

Agricultural Research Centre of Finland, South Ostrobothnia Research Station, FIN-61400 Ylistaro, Finland

Timo Mela

Agricultural Research Centre of Finland, Plant Production Research, FIN-31600 Jokioinen, Finland

Unto Nikunen

Agricultural Research Centre of Finland, North Ostrobothnia Research Station, Toholampi, FIN-69310 Laitala, Finland

Hannu Tuuri

Agricultural Research Centre of Finland, Data and Information Services, FIN-31600 Jokioinen, Finland

Martti Vuorinen

Agricultural Research Centre of Finland, Häme Research Station, FIN-36600 Pälkäne, Finland

The effect of the time of incorporation of different green manures and barley residues on the grain yield of spring cereals in two successive seasons was studied in seven field trials. Annual hairy vetch (Vicia villosa Roth), red clover (Trifolium pratense L.), westerwold ryegrass (Lolium multiflorum Lam. var. westerwoldicum) and straw of spring barley (Hordeum vulgare L.) were incorporated into the soil by ploughing in early September, late October and the following May, and by reduced tillage in May. Spring barley was established in the following spring, and spring oats (Avena sativa L.) one year later.

In general the grain yield of spring barley after legumes was similar to that after barley, in spite of the fact that $\mathrm{N}$ fertilization was reduced by $40 \mathrm{~kg} \mathrm{ha}^{-1}$. The two autumn ploughing treatments resulted in a good yield of spring barley more reliably than did the spring incorporations. Because delayed autumn ploughing did not decrease the grain yield, a delaying procedure can be recommended for its potential of decreasing nitrogen leaching. Spring ploughing could be used on all but clay soils. Incorporating ryegrass or red clover in spring by using reduced tillage often decreased the grain yield of barley. Timing of incorporation did not have a consistent effect on the grain yield of oats in the third experimental year.

Key words: Avena sativa, decomposition, green manures, Hordeum vulgare, legumes, Lolium multiflorum, mineralization, mulching, Trifolium pratense, Vicia villosa

(C) Agricultural and Food Science in Finland

Manuscript received January 1999 
Känkänen, H. et al. Timing of plant biomass incorporation: effect on cereal grain yield

\section{Introduction}

The residual effect of a green manure crop is highly dependent on the species grown (Wallgren and Lindén 1991). Legumes are generally considered to leave high amounts of $\mathrm{N}$ for the succeeding crop (Badaruddin and Meyer 1990), although there are great differences between legume crops in this respect (Kirchmann and Marstorp 1991). In Finland, cool late autumn weather and cold winter can decrease the decomposition rate of plant material and nitrification of nitrogenous compounds in soil (Anderson 1960). However, mineralization processes has been found to occur at low temperatures, too (Müller and Sundman 1988, Van Schöll et al. 1997).

On the basis of experiments with several different green fallow crops, delayed ploughing in autumn was proposed mainly because of the reduced risk of N leaching (Känkänen 1993), which is in accordance with several other results (Haynes 1994). However, the measures needed to support good utilization of the green manure $\mathrm{N}$ by spring-sown crops in Finland are not fully understood. Delayed incorporation of green manure crops can be used to enhance synchronization of the release of $\mathrm{N}$ with the requirements of the succeeding crop. Incorporation of green manure crop in spring, immediately before the next crop is sown, may lead to too late $\mathrm{N}$ mineralization with respect to the need of the succeeding crop (Thorup-Kristensen 1996). Delaying incorporation of green manure crop in autumn can also affect the yield of the following crop: Sanderson and MacLeod (1994) found that potato planted in spring following lupin incorporated on 1 October had a higher tuber yield than did that following lupin incorporated on 1 September.

The method of incorporation of the crop residues can also affect the successive cereal grain yield, either because the $\mathrm{N}$ release from the incorporated plant material differs or there are other factors in the soil influencing yield, or both. Maillard and Vez (1991) noticed that cereal yield was higher when green manure was incorporat- ed lightly into the soil rather than by regular ploughing into the $20-25 \mathrm{~cm}$ soil layer. Direct drilling of grain sorghum into clover surface mulch was not recommended by Lemon et al. (1990), because N availability was not synchronous with the needs of the succeeding plant.

The positive effect of $\mathrm{N}$ rich plant biomass on the succeeding cereal grain yield is often reduced with increasing $\mathrm{N}$ fertilization (Badaruddin and Meyer 1990, Lindén and Wallgren 1993). Further, Francis and Knight (1993) state that after different tillage methods, differences in yields can be compensated with different amount of fertilizer $\mathrm{N}$.

The aim of the study was to investigate how the time of incorporation (early or late autumn ploughing, and spring incorporation by ploughing) of crops with different $\mathrm{N}$ content (hairy vetch, red clover and westerwold ryegrass, and straw of spring barley) affect the grain yield of the following spring cereal crop. Reduced tillage was added as an additional treatment as this practise is increasingly common in cereal cropping in Finland. The effects of different $\mathrm{N}$ fertilization rates of the following crop on the differences between the effects of other treatments was studied, too.

\section{Material and methods}

Hairy vetch (Vicia villosa Roth), red clover (Trifolium pratense L.), westerwold ryegrass ( $\mathrm{Lo}$ lium multiflorum Lam. var. westerwoldicum) and straw residues of spring barley (Hordeum vulgare L.) were incorporated into the soil by ploughing in early autumn (beginning of September), late autumn (end of October) and spring (May) and by reduced tillage in spring. Incorporation times were determined according to normal practices in cereal farming in Finland, autumn ploughing period starting after crop harvest and ending when soil is frozen or too wet for ploughing. Time of spring tillage was determined according to soil moisture suitable for 
Vol. 8 (1999): 285-298.

sowing. The experimental sites, design, treatments and samplings are described in detail by Känkänen et al. (1998). Spring barley and oats (Avena sativa L.) were harvested with a combine harvester when ripe ( $1.5 \mathrm{~m} \mathrm{x} 7 \mathrm{~m}$ per plot). After the grains had been dried in an air stream $\left(+40^{\circ} \mathrm{C}\right)$ and sorted, the grain yield was measured and calculated as $\mathrm{kg} \mathrm{ha}^{-1}$ at $15 \%$ moisture.

Information on weather conditions during the experimental years is given in detail by Känkänen et al. (1998), and in Table 1.

The names of the trials are abbreviated as follows: Jokioinen 1991-1993 = J1, Jokioinen 1993-1995 = J2, Pälkäne 1991-1993 = P1, Pälkäne 1993-1995 = P2, Ylistaro 1991-1993 = Y1, Ylistaro 1993-1995 = Y2 and Toholampi $1991-1993=\mathrm{T}$. The crop of the first experimental year (green manures and spring barley) is called precrop, the crop of the second experimental year (spring barley) is called 1st year test crop, and the crop of the third experimental year (oats) is called 2 nd year test crop.

\section{Statistical methods}

The data from the seven different field trials were analysed separately. The main effects of precrop, incorporation treatment and $\mathrm{N}$ fertilization, and their interactions, on the grain yield of 1 st year test crop (spring barley) were tested statistically by analysis of variance according to the splitsplit-plot design. Replication was considered a random effect, whereas precrop, incorporation treatment and $\mathrm{N}$ fertilization were considered fixed effects. Precrop was analysed as a main plot factor, incorporation treatment as a subplot factor and $\mathrm{N}$ fertilization as a sub-subplot factor.

If significant interaction between $\mathrm{N}$ fertilization and other treatments were found, the differences of the effect of $\mathrm{N}$ fertilization in different treatment combinations were examined, else significant effects of the precrop and incorporation treatment and their interactions were examined over all $\mathrm{N}$ fertilization levels. If an interaction between the precrop and incorporation treat- ment was found, the effects of incorporation treatments were determined separately for different precrops. The differences were examined in pairs, and the means were compared by t-type contrast examinations. When there was no interaction, but the main effect was due to the precrop or incorporation treatment, the paired comparisons were made by Tukey's honest signicant difference (HSD) methods.

Before the analysis of variance was performed, the consistency of different examinations with the assumptions of equality of group variances were checked by Box-Cox diagnostic plots. In addition the normality assumption of errors was assessed by graphic methods. All analyses were performed by means of the SAS statistical package. MIXED (SAS 1992), UNIVARIATE (SAS 1990) and GPLOT (SAS 1991) procedures were used.

\section{Results}

\section{Precrop yields}

The dry matter yields of green manure crops varied, depending on site, year, species and sampling date (Table 2). In autumn, we measured $5000-8000 \mathrm{~kg} \mathrm{ha}^{-1}$ dry matter of hairy vetch. However, in the succeeding spring the detectable amount of dry matter in material left on the soil surface was only $2000-6000 \mathrm{~kg} \mathrm{ha}^{-1}$. In red clover (total dry matter ranging from 1800 to $9500 \mathrm{~kg} \mathrm{ha}^{-1}$ ), this was found at both Jokioinen and Toholampi in 1991-1992. A great proportion (as an average 50\%) of the red clover dry matter was in roots, and the amount in red clover grown annually increased sharply between samplings before early (12-38\%) and late autumn (49-65\%) ploughing. In contrast, the dry matter yield of vetch was mainly in aboveground plant biomass. The dry matter yield of westerwold ryegrass ranged from 2500 to 7000 $\mathrm{kg} \mathrm{ha}^{-1}$. The average $\mathrm{N}$ content of the aboveground plant biomass varied between trials from 
Känkänen, H. et al. Timing of plant biomass incorporation: effect on cereal grain yield

Table 1. Weather conditions at the experimental sites in experimental years (data provided by the Finnish Meteorological Institute) and in 1961-1990 (Finnish Meteorological Institute 1991).

\begin{tabular}{|c|c|c|c|c|c|c|c|c|c|c|c|c|}
\hline & \multicolumn{6}{|c|}{ Mean air temperature, ${ }^{\circ} \mathrm{C}$} & \multicolumn{6}{|c|}{ Precipitation, $\mathrm{mm}$} \\
\hline & 1991 & 1992 & 1993 & 1994 & 1995 & $\begin{array}{l}1961- \\
1990\end{array}$ & 1991 & 1992 & 1993 & 1994 & 1995 & $\begin{array}{l}1961- \\
1990\end{array}$ \\
\hline \multicolumn{13}{|l|}{ Jokioinen } \\
\hline January & -3.6 & $-2,1$ & 2.3 & -4.8 & -3.6 & -7.5 & 69 & 50 & 56 & 52 & 46 & 36 \\
\hline February & -7.5 & -2.7 & -3.4 & -13.9 & -1.0 & -7.4 & 16 & 31 & 16 & 1 & 58 & 24 \\
\hline March & -1.0 & 0.4 & -0.9 & -3.2 & -0.3 & 3.5 & 31 & 43 & 29 & 54 & 45 & 25 \\
\hline April & 3.4 & 1.3 & 3.3 & 5.0 & 2.7 & 2.4 & 14 & 48 & 29 & 33 & 47 & 32 \\
\hline May & 7.2 & 11.4 & 13.5 & 7.8 & 8.7 & 9.4 & 29 & 7 & 1 & 34 & 87 & 35 \\
\hline June & 12.1 & 15.6 & 11.4 & 12.1 & 16.7 & 14.3 & 69 & 25 & 56 & 66 & 121 & 47 \\
\hline July & 16.6 & 16.0 & 15.6 & 19.0 & 15.3 & 15.8 & 55 & 47 & 107 & 1 & 53 & 80 \\
\hline August & 16.2 & 14.3 & 12.9 & 15.1 & 15.1 & 14.2 & 92 & 107 & 136 & 54 & 65 & 83 \\
\hline September & 9.1 & 11.2 & 5.7 & 10.0 & 10.3 & 9.4 & 80 & 59 & 13 & 105 & 45 & 65 \\
\hline October & 5.4 & -0.6 & 3.0 & 4.4 & 7.6 & 4.7 & 49 & 64 & 51 & 75 & 66 & 58 \\
\hline November & 2.6 & -1.8 & -3.6 & -1.0 & -2.8 & -0.4 & 81 & 63 & 3 & 24 & 47 & 55 \\
\hline December & -1.6 & 0.1 & -3.4 & -0.4 & -8.5 & -4.9 & 34 & 33 & 61 & 51 & 19 & 42 \\
\hline Year & 4.9 & 5.3 & 4.3 & 4.2 & 5.0 & 3.9 & 619 & 577 & 558 & 551 & 698 & 582 \\
\hline \multicolumn{13}{|l|}{ Pälkäne } \\
\hline January & -4.6 & -2.9 & -2.8 & -5.8 & -4.0 & -8.2 & 40 & 37 & 41 & 50 & 52 & 36 \\
\hline February & -8.2 & -3.1 & -3.4 & -14.6 & -1.5 & -8.0 & 13 & 39 & 16 & 2 & 58 & 25 \\
\hline March & -1.4 & 0.3 & -0.9 & -3.2 & -0.4 & -3.6 & 33 & 47 & 31 & 54 & 36 & 27 \\
\hline April & 3.4 & 0.6 & 2.6 & 4.5 & 2.1 & 2.2 & 17 & 56 & 25 & 43 & 26 & 32 \\
\hline May & 7.5 & 11.5 & 13.3 & 7.9 & 8.8 & 9.5 & 22 & 8 & 3 & 48 & 65 & 37 \\
\hline June & 12.8 & 16.2 & 11.6 & 12.7 & 17.0 & 14.7 & 88 & 30 & 46 & 75 & 76 & 50 \\
\hline July & 17.3 & 15.8 & 15.7 & 19.2 & 15.6 & 16.3 & 41 & 58 & 75 & 5 & 37 & 74 \\
\hline August & 16.6 & 14.1 & 13.1 & 15.5 & 15.5 & 14.6 & 103 & 136 & 128 & 75 & 60 & 82 \\
\hline September & 9.5 & 11.5 & 5.9 & 10.3 & 10.5 & 9.7 & 68 & 105 & 18 & 84 & 33 & 64 \\
\hline October & 5.5 & -0.6 & 3.0 & 4.3 & 7.5 & 4.7 & 36 & 67 & 59 & 75 & 51 & 58 \\
\hline November & 2.5 & -2.7 & -4.0 & -1.4 & -2.9 & -0.7 & 65 & 61 & 5 & 35 & 48 & 50 \\
\hline December & -2.1 & -0.3 & -4.0 & -1.0 & -9.5 & -5.4 & 44 & 25 & 53 & 38 & 26 & 40 \\
\hline \multirow{2}{*}{\multicolumn{13}{|c|}{ Ylistaro }} \\
\hline & & & & & & & & & & & & \\
\hline January & -4.1 & -2.9 & -3.0 & -6.7 & -3.8 & -8.6 & 25 & 43 & 40 & 25 & 19 & 31 \\
\hline February & -8.9 & -2.6 & -3.8 & -13.8 & -2.3 & -8.4 & 14 & 31 & 14 & 1 & 39 & 21 \\
\hline March & -1.7 & 0.6 & -0.8 & -3.6 & -0.1 & -4.1 & 39 & 36 & 17 & 38 & 52 & 23 \\
\hline April & 3.9 & 0.2 & 3.1 & 4.2 & 2.1 & 2.0 & 12 & 23 & 23 & 26 & 22 & 29 \\
\hline May & 6.5 & 10.9 & 11.6 & 6.8 & 7.7 & 8.8 & 56 & 13 & 16 & 7 & 44 & 38 \\
\hline June & 12.3 & 15.1 & 10.9 & 12.5 & 16.1 & 14.0 & 147 & 18 & 84 & 81 & 75 & 42 \\
\hline July & 16.4 & 14.5 & 15.2 & 17.8 & 14.9 & 15.5 & 26 & 77 & 86 & 28 & 45 & 68 \\
\hline August & 15.7 & 13.2 & 12.6 & 14.4 & 14.1 & 13.6 & 60 & 103 & 122 & 52 & 34 & 70 \\
\hline September & 7.9 & 10.4 & 5.4 & 9.1 & 9.6 & 8.8 & 88 & 91 & 26 & 56 & 48 & 61 \\
\hline October & 5.2 & -2.6 & 2.5 & 3.1 & 6.8 & 4.1 & 38 & 62 & 78 & 83 & 42 & 50 \\
\hline November & 2.2 & -3.7 & -3.1 & -2.0 & -3.7 & -1.4 & 49 & 47 & 10 & 31 & 25 & 45 \\
\hline December & -2.0 & 0.2 & -5.1 & -0.8 & -9.8 & -6.2 & 25 & 41 & 51 & 25 & 12 & 35 \\
\hline Year & 4.5 & 4.4 & 3.8 & 3.4 & 4.3 & 3.2 & 578 & 584 & 568 & 452 & 458 & 513 \\
\hline \multicolumn{13}{|l|}{ Toholampi } \\
\hline January & -6.4 & -4.1 & -4.4 & & & -10.5 & 32 & 55 & 62 & & & 35 \\
\hline February & -9.1 & -4.6 & -4.5 & & & -10.0 & 18 & 29 & 20 & & & 24 \\
\hline March & -4.3 & -1.8 & -1.7 & & & -5.3 & 34 & 51 & 27 & & & 28 \\
\hline April & 2.6 & 1.9 & 2.0 & & & 0.9 & 24 & 12 & 26 & & & 30 \\
\hline May & 5.5 & 10.0 & 10.8 & & & 8.1 & 38 & 10 & 20 & & & 38 \\
\hline June & 11.6 & 10.2 & 10.4 & & & 13.4 & 108 & 15 & 17 & & & 49 \\
\hline July & 15.6 & 15.2 & 15.8 & & & 15.4 & 35 & 138 & 70 & & & 67 \\
\hline August & 14.8 & 12.2 & 12.5 & & & 13.1 & 61 & 107 & 82 & & & 79 \\
\hline September & 6.9 & 9.6 & 4.7 & & & 7.8 & 110 & 99 & 34 & & & 59 \\
\hline October & 4.1 & -3.2 & 1.6 & & & 2.8 & 46 & 47 & 99 & & & 49 \\
\hline November & 1.1 & -5.0 & -3.6 & & & -2.9 & 65 & 75 & 7 & & & 48 \\
\hline December & -3.6 & -0.6 & -5.7 & & & -7.9 & 33 & 48 & 76 & & & 38 \\
\hline Year & 3.2 & 3.3 & 3.2 & & & 2.1 & 604 & 686 & 540 & & & 544 \\
\hline
\end{tabular}


Vol. 8 (1999): 285-298.

Table 2. Above-ground and root dry matter yield $\left(\mathrm{kg} \mathrm{ha}^{-1}\right)$ and $\mathrm{N}$ content $(\%$, in parentheses) of green manure crops. J1 = Jokioinen 1991-1993, J2 = Jokioinen 1993-1995, P1 = Pälkäne 1991-1993, T = Toholampi 1991-1993.

\begin{tabular}{|c|c|c|c|c|c|c|}
\hline & \multicolumn{3}{|c|}{ Above-ground dry matter } & \multicolumn{3}{|c|}{ Root dry matter $(0-20 \mathrm{~cm})$} \\
\hline & $\begin{array}{l}\text { Hairy } \\
\text { vetch }\end{array}$ & $\begin{array}{l}\text { Red } \\
\text { clover }\end{array}$ & $\begin{array}{c}\text { Westerwold } \\
\text { ryegrass }\end{array}$ & $\begin{array}{l}\text { Hairy } \\
\text { vetch }\end{array}$ & $\begin{array}{l}\text { Red } \\
\text { clover }\end{array}$ & $\begin{array}{c}\text { Westerwold } \\
\text { ryegrass }\end{array}$ \\
\hline \multicolumn{7}{|l|}{$J 1$} \\
\hline Early autumn & $6910(3.1)$ & $5280(3.0)$ & $4380(0.9)$ & $240(1.5)$ & $1960(2.0)$ & $880(0.7)$ \\
\hline Late autumn & $7510(3.1)$ & $3510(2.4)$ & $3900(1.2)$ & $220(1.9)$ & $6030(2.2)$ & $1090(0.9)$ \\
\hline Spring & $1850(2.2)$ & $1160(3.0)$ & $1950(1.1)$ & $280(2.2)$ & $660(3.0)$ & $680(1.2)$ \\
\hline Reduced tillage & $2170(2.3)$ & $1180(2.7)$ & $2110(0.9)$ & $200(2.6)$ & $1770(3.1)$ & $1250(0.8)$ \\
\hline \multicolumn{7}{|l|}{$J 2$} \\
\hline Early autumn & $6170(3.2)$ & $2560(3.2)$ & $3160(1.7)$ & $710(3.3)$ & $1550(2.4)$ & $2150(1.2)$ \\
\hline Late autumn & $4670(4.0)$ & $3410(3.4)$ & $3610(1.9)$ & $810(2.4)$ & $3240(2.7)$ & $1290(1.4)$ \\
\hline Spring & $2000(3.0)$ & $2790(3.4)$ & $1810(1.7)$ & $250(2.2)$ & $2480(3.0)$ & $1310(1.1)$ \\
\hline Reduced tillage & $3970(2.7)$ & $2080(3.3)$ & $2100(1.8)$ & $720(2.0)$ & $2210(3.2)$ & $1620(1.0)$ \\
\hline \multicolumn{7}{|l|}{$P 1$} \\
\hline Early autumn & $6330(3.0)$ & $2280(2.0)$ & $2760(0.9)$ & $780(1.6)$ & $1410(1.0)$ & $2730(0.8)$ \\
\hline Late autumn & $6730(2.9)$ & $2650(2.0)$ & $2520(1.0)$ & $2110(1.4)$ & $4820(1.6)$ & $3110(0.7)$ \\
\hline Spring & $3320(2.5)$ & $2720(2.1)$ & $3760(0.8)$ & $2250(-)$ & $3650(-)$ & $3200(-)$ \\
\hline Reduced tillage & $4750(2.4)$ & $2290(2.1)$ & $3180((0.7)$ & $1890(-)$ & $4750(-)$ & $3000(-)$ \\
\hline \multicolumn{7}{|l|}{$T$} \\
\hline Early autumn & $4490(2.7)$ & $2210(1.6)$ & $5390(0.8)$ & $240(1.8)$ & $290(1.5)$ & $750(1.1)$ \\
\hline Late autumn & $4610(3.3)$ & $1750(2.1)$ & $1150(1.0)$ & $940(1.2)$ & $1520(1.6)$ & $1440(1.1)$ \\
\hline Spring & $1800(2.7)$ & $710(2.2)$ & $1130(1.3)$ & $390(1.5)$ & $1860(1.5)$ & $2050(1.4)$ \\
\hline Reduced tillage & $1680(2.7)$ & $900(2.5)$ & $1350(1.2)$ & $340(1.5)$ & $1720(1.6)$ & $2960(1.1)$ \\
\hline
\end{tabular}

2.1 to $3.1 \%, 1.2$ to $3.4 \%, 0.9$ to $1.8 \%$ and 0.8 to $1.4 \%$ in vetch, red clover, ryegrass and barley straw, respectively. The respevtive root $\mathrm{N}$ content ranged from 1.5 to $3.0 \%, 1.3$ to $2.8 \%, 0.8$ to $1.7 \%$ and 1.1 to $1.9 \%$. Total $\mathrm{N}$ yield ranged from 45 to 240,40 to 220 and 25 to $90 \mathrm{~kg} \mathrm{ha}^{-1}$ in vetch, red clover and ryegrass, respectively. The amount of $\mathrm{N}$ in plant biomass is more closely presented in our earlier article (Känkänen et al. 1998). The amount of incorporated barley straw was determined only in two trials: the total $\mathrm{N}$ yield in autumn was $90 \mathrm{~kg} \mathrm{ha}^{-1}$ in $\mathrm{P} 1$ and $50 \mathrm{~kg}$ $\mathrm{ha}^{-1}$ in $\mathrm{T}$.

\section{Grain yield of Ist year test crop}

The grain yield of the 1st year test crop (spring barley) differed markedly at the experimental sites. The lowest (J1) and highest (Y1) average grain yield varied from 500 to $5100 \mathrm{~kg} \mathrm{ha}^{-1}$. Unless otherwise mentioned, the differences between treatments are statistically significant at the level $\mathrm{P}<0.05$ (Table 3 ). Grain yields presented below are calculated as the means over $\mathrm{N}$ fertilization levels, because $\mathrm{N}$ fertilization normally increased the grain yield in spite of other treatments. The few exceptions showing significant interaction are examined more closely later in the text.

The precrop affected the grain yield of the 1st year test crop in four trials (P1, P2, Y2, T); the poor grain yield after red clover in three of these trials was partly caused by decreased $\mathrm{N}$ fertilization. The incorporation treatment affected the grain yield of 1 st year test crop in all trials except Y2. However, in trials P2, Y1 and T the effect of incorporation depended on the precrop. 
Känkänen, H. et al. Timing of plant biomass incorporation: effect on cereal grain yield

Table 3. Statistical significances of the main effects of the treatments and their interactions on grain yield of 1st year test crop (spring barley) and 2nd year test crop (oats). Degrees of freedom of F test are in subscript after treatments. J1 = Jokioinen 1991-1993, J2 = Jokioinen 1993-1995, P1 = Pälkäne 1991-1993, P2 = Pälkäne1993-1995, Y1 = Ylistaro 1991-1993, Y2 = Ylistaro 1993-1995, T = Toholampi 1991-1993.

\begin{tabular}{|c|c|c|c|c|c|c|c|}
\hline & $J 1$ & $J 2$ & $P 1$ & $P 2$ & $Y 1$ & $Y 2$ & $T$ \\
\hline \multicolumn{8}{|l|}{ 1st year test crop } \\
\hline Precrop $_{3,6}$ & 0.89 & 0.56 & 0.03 & $<0.001$ & 0.45 & 0.027 & 0.009 \\
\hline Incorporation & $<0.001$ & 0.046 & 0.003 & $<0.001$ & 0.17 & 0.29 & $<0.001$ \\
\hline Precrop $\mathrm{x}$ incorporation & 0.71 & 0.9 & 0.52 & 0.002 & 0.027 & 0.85 & 0.033 \\
\hline $\mathrm{N}$ fertilization 2,64 & 0.007 & $<0.001$ & $<0.001$ & $<0.001$ & $<0.001$ & $<0.001$ & $<0.001$ \\
\hline Precrop $\mathrm{x}$ fertilization & 0.26 & 0.11 & 0.48 & $<0.001$ & 0.46 & 0.17 & 0.052 \\
\hline Incorp. $\mathrm{x}$ fertilization ${ }_{6,64}$ & 0.47 & 0.57 & 0.52 & 0.012 & 0.39 & 0.77 & 0.16 \\
\hline Precr. $\mathrm{x}$ incorp. $\mathrm{x}$ fertil. ${ }_{18,64}$ & 0.38 & 0.88 & 0.28 & 0.95 & 0.63 & 0.69 & 0.033 \\
\hline \multicolumn{8}{|l|}{ 2nd year test crop } \\
\hline Precrop $_{3,6}$ & 0.83 & 0.98 & 0.057 & 0.17 & 0.39 & 0.91 & 0.63 \\
\hline Incorporation $_{3,24}$ & 0.11 & 0.39 & 0.14 & 0.33 & 0.052 & 0.11 & 0.003 \\
\hline Precrop x incorporation 9,24 & 0.24 & 0.29 & 0.22 & 0.44 & 0.15 & 0.73 & 0.11 \\
\hline $\mathrm{N}$ fertilization ${ }_{2,64}$ & 0.024 & 0.003 & 0.58 & 0.65 & 0.26 & 0.96 & 0.16 \\
\hline Precrop $\mathrm{x}$ fertilization $_{6,64}$ & 0.74 & 0.006 & 0.18 & 0.68 & 0.65 & 0.46 & 0.55 \\
\hline Incorp. $\mathrm{x}$ fertilization $_{6,64}$ & 0.58 & 0.59 & 0.2 & 0.21 & 0.35 & 0.95 & 0.014 \\
\hline Precr. $\mathrm{x}$ incorp. $\mathrm{x}$ fertil. ${ }_{18,64}$ & 0.31 & 0.95 & 0.021 & 0.37 & 0.42 & 0.71 & 0.27 \\
\hline
\end{tabular}

\section{Effect of precrop}

The grain yield of the 1st year test crop showed that hairy vetch had the expected $40 \mathrm{~kg} \mathrm{ha}^{-1} \mathrm{~N}$ effect; in one trial (P1), this effect was even higher (Fig. 1). Although the increase in the yield of 1st year test crop after vetch was high compared with that after barley in $\mathrm{J} 2,1100 \mathrm{~kg} \mathrm{ha}^{-1}$, the effect of the precrop was not statistically significant.

The differences between the grain yields of 1 st year test crop after red clover and barley were small in three trials ( $\mathrm{J} 1, \mathrm{P} 1, \mathrm{Y} 1)$ in spite of 40 $\mathrm{kg} \mathrm{ha}^{-1}$ lower $\mathrm{N}$ fertilization after red clover (Fig. 1, Table 4). In three trials (P2, Y2, T), the grain yield of 1st year test crop was lower after red clover than after barley. In these trials also $\mathrm{N}$ yield of red clover was lower than in other trials, above ground $\mathrm{N}$ yield being $20-30 \mathrm{~kg} \mathrm{ha}^{-1}$ in the former trials and 50-90 kg ha ${ }^{-1}$ in the latter. However, in trials P2 and T the differences between precrops varied, depending on the incorporation treatment (Table 4 ). The average grain yield of 1st year test crop after the $90 \mathrm{~kg} \mathrm{~N} \mathrm{ha}^{-1}$ above ground yield of red clover in $\mathrm{J} 2$ was more than $200 \mathrm{~kg} \mathrm{ha}^{-1}$ higher than that of after barley; the difference was not statistically significant, however.

In one trial (P2), the average grain yield of 1 st year test crop was clearly smaller after westerwold ryegrass than after barley, although the difference varied depending on the incorporation treatment. The average grain yield of $1 \mathrm{st}$ year test crop was, however, $500 \mathrm{~kg} \mathrm{ha}^{-1}$ higher after westerwold ryegrass than after barley in three trials (J2, Y1, T). The differences were not statistically significant.

\section{Effect of incorporation treatment}

According to the grain yield of 1 st year test crop, both ploughing dates in autumn were suitable at all experimental sites after all precrops (Fig. 2, Table 4), except in Y1, in which late autumn ploughing of westerwold ryegrass decreased the grain yield of 1 st year test crop by an average of $550-840 \mathrm{~kg} \mathrm{ha}^{-1}$ as compared with the other incorporation treatments. After hairy vetch and barley a similar tendency was seen, but the difference (on average $300 \mathrm{~kg} \mathrm{ha}^{-1}$ ) was not statistically significant (Table 4). 


\section{AGRICULTURAL AND FOOD SCIENCE IN FINLAND}

Vol. 8 (1999): 285-298.

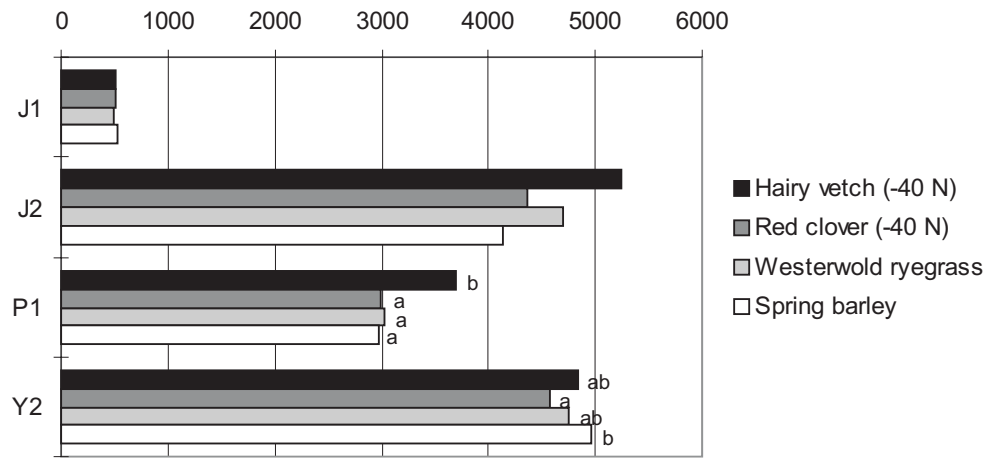

Fig. 1. The main effect of the precrop on grain yield of 1st year test crop (spring barley) in trials with no interactions between incorporation and precrop. The bars are based on means of all incorporation and $\mathrm{N}$ fertilization treatments, reduced by $40 \mathrm{~kg} \mathrm{ha}^{-1}$ after legumes (standard error of means, SEM: J1 = 41, J2 = 558, P1 = 352, $\mathrm{Y} 2=187 \mathrm{~kg} \mathrm{ha}^{-1}$ ). Within trials, yields followed by the same letter are not statistically different at level $\mathrm{P}<0.05$. There was a statistically significant interaction between precrop and incorporation treatment in trial P2, Y1 and T; results presented in Table 4. J1 = Jokioinen 1991-1993, J2 = Jokioinen 1993-1995, P1 = Pälkäne 1991-1993, P2 = Pälkäne 1993-1995, Y1 = Ylistaro 1991-1993, Y2 = Ylistaro 1993-1995, $\mathrm{T}=$ Toholampi 1991-1993.

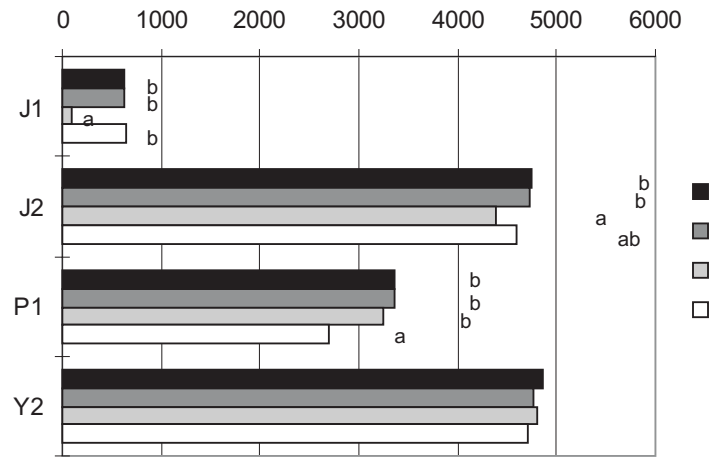

Ploughing, early autumn

$\square$ Ploughing, late autumn $\square$ Ploughing, spring

$\square$ Reduced tillage, spring

Fig. 2. The main effect of incorporation treatment on grain yield of 1 st year test crop (spring barley) in trials with no interactions between incorporation and precrop. The bars are based on means of all precrops and $\mathrm{N}$ fertilization treatments, reduced by $40 \mathrm{~kg} \mathrm{ha}^{-1}$ after legumes (standard error of means, SEM: J1 = 41, J2 = 291, P1 = 348, $\left.\mathrm{Y} 2=184 \mathrm{~kg} \mathrm{ha}^{-1}\right)$. Within trials, yields followed by the same letter are not statistically different at level $\mathrm{P}<0.05$. There was a statistically significant interaction between precrop and incorporation treatment in trial P2, Y1 and T; results presented in Table 4. J1 = Jokioinen 1991-1993, J2 = Jokioinen 1993-1995, P1 = Pälkäne 1991-1993, P2 = Pälkäne 1993-1995, Y1 = Ylistaro 1991-1993, Y2 = Ylistaro 1993-1995, $\mathrm{T}=$ Toholampi 1991-1993. 
Känkänen, H. et al. Timing of plant biomass incorporation: effect on cereal grain yield

Table 4. Effect of incorporation treatment of different precrops on the succeeding 1st year test crop (spring barley) grain yield $\left(\mathrm{kg} \mathrm{ha}^{-1}\right)$ in trials with interactions between incorporation and precrop. The figures are means of $\mathrm{N}$ fertilization treatments, reduced by $40 \mathrm{~kg} \mathrm{ha}^{-1}$ after legumes. The main effect of precrop and incorporation is presented in 'average' columns and rows. P2 = Pälkäne 1993-1995, Y1 = Ylistaro 19911993, T = Toholampi 1991-1993.

\begin{tabular}{lccccc}
\hline & $\begin{array}{c}\text { Hairy } \\
\text { vetch }\end{array}$ & $\begin{array}{c}\text { Red } \\
\text { clover }\end{array}$ & $\begin{array}{r}\text { Westerwold } \\
\text { ryegrass }\end{array}$ & $\begin{array}{r}\text { Spring } \\
\text { barley }\end{array}$ & Average \\
\hline P2 (SEM 130) & & & & $\begin{array}{r}(\text { SEM 65) } \\
\text { Early autumn }\end{array}$ \\
Late autumn & $3100^{\mathrm{ab}}$ & $2210^{\mathrm{b}}$ & $2550 \mathrm{c}$ & $2940^{\mathrm{b}}$ & $2700^{\mathrm{b}}$ \\
Spring & $3280^{\mathrm{b}}$ & $2170^{\mathrm{b}}$ & $2460^{\mathrm{bc}}$ & $2610^{\mathrm{a}}$ & $2630^{\mathrm{b}}$ \\
Reduced tillage & $2970^{\mathrm{a}}$ & $1770^{\mathrm{a}}$ & $2200^{\mathrm{ab}}$ & $2790^{\mathrm{ab}}$ & $2430^{\mathrm{a}}$ \\
Average (SEM 137) & $3100^{\mathrm{ab}}$ & $1550^{\mathrm{a}}$ & $1960^{\mathrm{a}}$ & $2950^{\mathrm{b}}$ & $2390^{\mathrm{a}}$ \\
Y1 (SEM 434) & $3110^{\mathrm{g}}$ & $1920^{f}$ & $2290^{f}$ & $2820^{\mathrm{g}}$ & \\
Early autumn & & & & $($ SEM 324) \\
Late autumn & $4920^{\mathrm{a}}$ & $4850^{\mathrm{b}}$ & $5550^{\mathrm{b}}$ & $5130^{\mathrm{a}}$ & 5110 \\
Spring & $4850^{\mathrm{a}}$ & $5150^{\mathrm{b}}$ & $5000^{\mathrm{a}}$ & $4670^{\mathrm{a}}$ & 4920 \\
Reduced tillage & $5270^{\mathrm{a}}$ & $4960^{\mathrm{b}}$ & $5650^{\mathrm{b}}$ & $4970^{\mathrm{a}}$ & 5210 \\
Average (SEM 405) & $5100^{\mathrm{a}}$ & $4340^{\mathrm{a}}$ & $5840^{\mathrm{b}}$ & $5130^{\mathrm{a}}$ & 5100 \\
$T$ (SEM 225) & 5030 & 4830 & 5510 & 4980 & \\
Early autumn & & & & $4760^{\mathrm{b}}$ & $($ SEM 144) \\
Late autumn & $5080^{\mathrm{b}}$ & $3930^{\mathrm{b}}$ & $4830^{\mathrm{ab}}$ & $4650^{\mathrm{b}}$ & $4600^{\mathrm{b}}$ \\
Spring & $4640^{\mathrm{b}}$ & $4290^{\mathrm{b}}$ & $4840^{\mathrm{ab}}$ & $4400^{\mathrm{b}}$ & $4710^{\mathrm{b}}$ \\
Reduced tillage & $4950^{\mathrm{b}}$ & $4420^{\mathrm{b}}$ & $5090^{\mathrm{b}}$ & $3650^{\mathrm{a}}$ & $3630^{\mathrm{a}}$ \\
Average (SEM 165) & $3730^{\mathrm{a}}$ & $2710^{\mathrm{a}}$ & $4410^{\mathrm{a}}$ & $4360^{f g}$ & \\
\hline
\end{tabular}

Within columns, means followed by the same letter are not statistically different at level "P<0.05; the italic rows (Average) are excluded from this comparison. Within italic rows," means followed by the same letter are not statistically different at level $\mathrm{P}<0.05(\mathrm{P} 2, \mathrm{~T})$. Standard error of means (SEM) is presented for each comparison.

Ploughing in spring was not an advantageous on clay soil at Jokioinen (J1, J2), the grain yield of 1 st year test crop being 250-550 ka ha ${ }^{-1}$ lower than with autumn ploughing or reduced tillage in spring, irrespective of the precrop (Fig. 2). Even in P2 (sandy soil), incorporation of the green manure crops by ploughing in spring resulted in a smaller grain yield than did autumn ploughing (Table 4). In the other trials, the grain yield of 1 st year test crop after spring ploughing was about the same as that after autumn ploughings.

Although spring tillage with a cultivator was applicable on clay soil at Jokioinen, at other sites the grain yield of 1st year test crop was often smallest after reduced tillage in spring, especially after red clover. The grain yield of 1 st year test crop was smallest after reduced tillage in spring in two trials irrespective of the precrop $(\mathrm{P} 1, \mathrm{~T})$, in two trials with red clover $(\mathrm{P} 2, \mathrm{Y} 1)$ and in one trial (P2) with westerwold ryegrass as the precrop (Fig. 2, Table 4). In these cases, the difference between reduced spring tillage and autumn ploughing treatments was marked, on average $750 \mathrm{~kg} \mathrm{ha}^{-1}$.

\section{Effect of $N$ fertilization}

$\mathrm{N}$ fertilization clearly increased the grain yield of 1st year test crop (Table 5). However, in P2, $\mathrm{N}$ fertilization did not increase the grain yield after hairy vetch (interaction between precrop and $\mathrm{N}$ fertilization, $\mathrm{P}<0.001$ ), and the yield increase was smaller after early autumn plough- 
Vol. 8 (1999): 285-298.

Table 5. Effect of precrop, incorporation and $\mathrm{N}$ fertilization on the 1st year test crop (spring barley) grain yield $\left(\mathrm{kg} \mathrm{ha}^{-1}\right)$. Standard errors of means (SEM) are presented in parentheses after abbreviation of each trial. J1 = Jokioinen 1991-1993, J2 = Jokioinen 1993-1995, P1 = Pälkäne 1991-1993, P2 = Pälkäne 1993-1995, Y1 = Ylistaro 1991-1993, Y2 = Ylistaro 1993-1995, T = Toholampi 1991-1993.

\begin{tabular}{|c|c|c|c|c|c|c|c|c|c|c|c|c|}
\hline & \multicolumn{3}{|c|}{ Hairy vetch } & \multicolumn{3}{|c|}{ Red clover } & \multicolumn{3}{|c|}{ Westerwold ryegrass } & \multicolumn{3}{|c|}{ Spring barley } \\
\hline & $0 \mathrm{~N}$ & $40 \mathrm{~N}$ & $80 \mathrm{~N}$ & $\mathrm{ON}$ & $40 \mathrm{~N}$ & $80 \mathrm{~N}$ & $40 \mathrm{~N}$ & $80 \mathrm{~N}$ & $120 \mathrm{~N}$ & $40 \mathrm{~N}$ & $80 \mathrm{~N}$ & $120 \mathrm{~N}$ \\
\hline \multicolumn{13}{|l|}{$J 1$ (SEM 88) } \\
\hline Early autumn & 590 & 530 & 650 & 550 & 610 & 600 & 650 & 620 & 740 & 570 & 790 & 700 \\
\hline Late autumn & 550 & 590 & 740 & 700 & 740 & 640 & 580 & 640 & 720 & 560 & 620 & 540 \\
\hline Spring & 110 & 70 & 90 & 150 & 70 & 120 & 50 & 70 & 40 & 100 & 160 & 160 \\
\hline Reduced tillage & 660 & 790 & 720 & 620 & 650 & 620 & 360 & 620 & 710 & 620 & 650 & 760 \\
\hline \multicolumn{13}{|l|}{$J 2$ (SEM 638) } \\
\hline Early autumn & 4900 & 5380 & 6140 & 4270 & 4390 & 4650 & 4430 & 5340 & 4910 & 3720 & 4530 & 4090 \\
\hline Late autumn & 4620 & 5260 & 5650 & 4190 & 4140 & 5240 & 4240 & 5050 & 5340 & 3950 & 4310 & 4530 \\
\hline Spring & 4260 & 5260 & 5690 & 3970 & 4310 & 3880 & 3880 & 4630 & 4580 & 3820 & 4360 & 4030 \\
\hline Reduced tillage & 4630 & 5200 & 6020 & 3840 & 4890 & 4360 & 4590 & 4840 & 5020 & 3710 & 4180 & 4460 \\
\hline \multicolumn{13}{|l|}{$P 1$ (SEM 512) } \\
\hline Early autumn & 3560 & 3390 & 5290 & 2650 & 2880 & 3000 & 3110 & 3460 & 3700 & 2840 & 3270 & 3090 \\
\hline Late autumn & 3400 & 4090 & 4380 & 2210 & 3930 & 3230 & 2710 & 3400 & 3040 & 2620 & 3340 & 4060 \\
\hline Spring & 3170 & 3870 & 4050 & 2390 & 3220 & 3760 & 2810 & 3680 & 3380 & 2340 & 3240 & 3160 \\
\hline Reduced tillage & 2250 & 3460 & 3410 & 2290 & 2430 & 3900 & 1980 & 2420 & 2580 & 2320 & 2790 & 2620 \\
\hline \multicolumn{13}{|l|}{ P2 (SEM 187) } \\
\hline Early autumn & 3210 & 3030 & 3040 & 1970 & 2230 & 2420 & 2230 & 2700 & 2730 & 2620 & 3110 & 3100 \\
\hline Late autumn & 3290 & 3340 & 3200 & 1720 & 2210 & 2580 & 2110 & 2560 & 2710 & 2070 & 2920 & 2840 \\
\hline Spring & 2760 & 3100 & 3060 & 1340 & 1960 & 2010 & 1790 & 2380 & 2440 & 2350 & 3140 & 2900 \\
\hline Reduced tillage & 2930 & 2900 & 3470 & 1200 & 1470 & 1970 & 1240 & 2220 & 2410 & 2310 & 3040 & 3490 \\
\hline \multicolumn{13}{|l|}{$Y 1$ (SEM 503) } \\
\hline Early autumn & 4580 & 4700 & 5480 & 4600 & 4740 & 5220 & 5260 & 5350 & 6040 & 4780 & 5050 & 5550 \\
\hline Late autumn & 4360 & 4860 & 5310 & 4670 & 5030 & 5610 & 4520 & 5600 & 4880 & 4190 & 4490 & 5320 \\
\hline Spring & 4450 & 5580 & 5790 & 3900 & 5470 & 5510 & 5240 & 5680 & 6030 & 4770 & 5000 & 5150 \\
\hline Reduced tillage & 4240 & 5540 & 5500 & 3730 & 4160 & 5140 & 5490 & 6020 & 6010 & 4480 & 5050 & 5870 \\
\hline \multicolumn{13}{|l|}{$Y 2($ SEM 260) } \\
\hline Early autumn & 4970 & 5110 & 4800 & 4470 & 4800 & 4770 & 4830 & 4780 & 4860 & 4550 & 5290 & 4990 \\
\hline Late autumn & 4750 & 4850 & 4860 & 4080 & 4820 & 4670 & 4760 & 4830 & 4810 & 4860 & 5040 & 5130 \\
\hline Spring & 4680 & 5220 & 4840 & 4450 & 4600 & 5080 & 4330 & 4730 & 5020 & 4890 & 5090 & 4940 \\
\hline Reduced tillage & 4790 & 5060 & 4750 & 3990 & 4520 & 4700 & 4320 & 4740 & 4900 & 4550 & 5010 & 5240 \\
\hline \multicolumn{13}{|l|}{$T($ SEM 281$)$} \\
\hline Early autumn & 3670 & 5240 & 6340 & 2300 & 4190 & 5300 & 4060 & 4840 & 5580 & 3550 & 5010 & 5730 \\
\hline Late autumn & 2980 & 4770 & 6160 & 3260 & 4090 & 5510 & 3570 & 5010 & 5930 & 3230 & 4820 & 5890 \\
\hline Spring & 4170 & 4770 & 5900 & 3110 & 4410 & 5730 & 3870 & 5330 & 6060 & 3290 & 4850 & 5040 \\
\hline Reduced tillage & 2200 & 3970 & 5020 & 1690 & 2400 & 4050 & 3050 & 4570 & 5610 & 2390 & 3710 & 4830 \\
\hline
\end{tabular}

ing than after other incorporation treatments (interaction between incorporation and $\mathrm{N}$ fertilization, $\mathrm{P}=0.012)$. In one trial $(\mathrm{T})$, the yield-increase due to $\mathrm{N}$ fertilization after vetch and barley was smaller whith spring ploughing than oth- er incorporation treatments (interaction between precrop, incorporation and $\mathrm{N}$ fertilization, $\mathrm{P}=0.033$ ). The same phenomenon was found after westerwold ryegrass when early autumn ploughing was used. Even so, the yield-increas- 
Känkänen, H. et al. Timing of plant biomass incorporation: effect on cereal grain yield

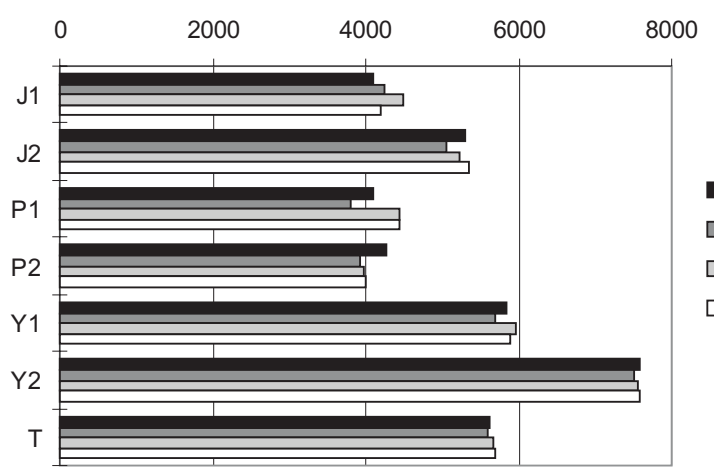

$\square$ Hairy vetch
$\square$ Red clover
$\square$ Westerwold ryegrass
$\square$ Spring barley

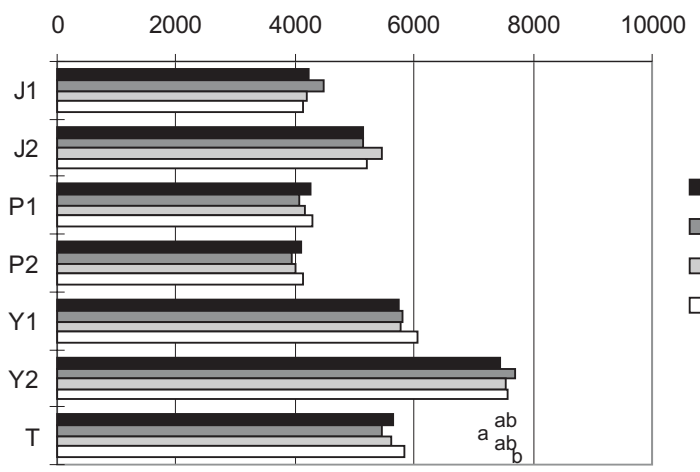

Ploughing, early autumn

Ploughing, late autumn

$\square$ Ploughing, spring

$\square$ Reduced tillage, spring
Fig. 3. The main effect of the precrop on grain yield of 2 nd year test crop (oats). The bars are based on means of treatments (standard error of means, SEM: J1 = 366, J2 = $579, \mathrm{P} 1=168, \mathrm{P} 2=102, \mathrm{Y} 1=198$, $\left.\mathrm{Y} 2=126, \mathrm{~T}=149 \mathrm{~kg} \mathrm{ha}^{-1}\right) . \mathrm{J} 1=$ Jokioinen 1991-1993, J2 = Jokioinen 1993-1995, P1 = Pälkäne 1991-1993, P2 = Pälkäne 19931995, Y1 = Ylistaro 1991-1993, Y2 = Ylistaro 1993-1995, T = Toholampi 1991-1993.

Fig. 4. The main effect of incorporation treatment after the precrop on grain yield of 2 nd year test crop (oats). The bars are based on means of treatments (standard error of means, SEM: J1 = 271, J2 = $399, \mathrm{P} 1=130, \mathrm{P} 2=87, \mathrm{Y} 1=189$, $\left.\mathrm{Y} 2=117, \mathrm{~T}=149 \mathrm{~kg} \mathrm{ha}^{-1}\right)$. Within trials, yields followed by the same letter are not statistically different at level $\mathrm{P}<0.05$. J1 = Jokioinen 1991-1993, J2 = Jokioinen 1993-1995, P1 = Pälkäne 1991-1993, P2 = Pälkäne 19931995, Y1 = Ylistaro 1991-1993, Y2 = Ylistaro 1993-1995, T = Toholampi 1991-1993. ing effect of $\mathrm{N}$ fertilization was clear in the above cases, too.

\section{Grain yield of 2nd year test crop}

\section{Effect of precrop}

The precrop did not have a statistically significant effect on the grain yield of 2nd year test crop (oats), although in all trials except $\mathrm{J} 1$ the yield was somewhat smaller (in J2, P1 and Y1 on average $200 \mathrm{~kg} \mathrm{ha}^{-1}$ ) after red clover than after other precrops (Fig. 3).

\section{Effect of incorporation treatment}

The incorporation treatment had a statistically significant effect on the grain yield of 2 nd year test crop in two trials, Y1 and T (Table 3). In these trials, the plots with reduced spring tillage in the preceding season increased the average grain yield of 2 nd year test crop by $200-400 \mathrm{~kg}$ $\mathrm{ha}^{-1}$ as compared with other incorporation treatments (Fig. 4).

\section{Effect of $N$ fertilization}

At Jokioinen (J1, J2), the lowest rate of $\mathrm{N}$ fertilization of 1 st year test crop resulted in a small- 
Vol. 8 (1999): 285-298.

er grain yield of 2 nd year test crop than did the two higher $\mathrm{N}$ fertilization levels. In $\mathrm{J} 1$, the differences between the lowest level and the two higher fertilization levels were about $200 \mathrm{~kg} \mathrm{ha}^{-1}$, irrespective of the other treatments. In J2, the differences varied considerably, depending on precrop (interaction between precrop and $\mathrm{N}$ fertilization, $\mathrm{P}=0.006$ ): the maximum difference was nearly $1000 \mathrm{~kg} \mathrm{ha}^{-1}$ with barley as a precrop, whereas there were no differences when red clover was the precrop. In other trials, $\mathrm{N}$ fertilization of 1st year test crop did not affect the grain yield of 2 nd year test crop. In two other individual cases, there was an interaction between $\mathrm{N}$ fertilization and other treatments (T: between incorporation and fertilization, $\mathrm{P}=0.014 ; \mathrm{P} 1$ : between precrop, incorporation and fertilization, $P=0.021$. Table 3). For these interactions we could not find any solid explanations.

\section{Discussion}

The ability of incorporated N-rich plant biomass to increase the succeeding cereal grain yield was expected, partly because $\mathrm{N}$ mineralized from the residues correlates positively with the crop $\mathrm{N}$ content (Vinther 1994, Clement et al. 1995), and partly because earlier results had suggested such an increase (Kauppila 1983, Känkänen 1993). The presumption of a $40 \mathrm{~kg} \mathrm{ha}^{-1}$ residual $\mathrm{N}$ effect after legumes was correct, although the effect of hairy vetch as a precrop exceeded this figure in some trials. Also the effect of red clover fell below the presumption, if the growth of clover was poor.

The study of soil mineral N (Känkänen et. al 1998), showed that early autumn ploughing increased soil mineral $\mathrm{N}$ at the beginning of the following growing season as compared with other incorporation times. Late autumn ploughing increased soil mineral $\mathrm{N}$ as compared with spring incorporation only when the soil mineral $\mathrm{N}$ content was exceptionally high. Soil conditions suitable for $\mathrm{N}$ mineralization after late autumn in- corporation was concluded to last generally too short time under Finnish conditions to result in substantial net $\mathrm{N}$ mineralization before spring. Thus the release of $\mathrm{N}$ from incorporated plant biomass during the following summer can be essential for the yield of the following crop, accordingly to Francis et al. (1994), who found that grain yield of spring wheat correlated positively with net $\mathrm{N}$ mineralization during the growing season after crops with a different $\mathrm{N}$ content.

Francis et al. (1994) also found that grain yield of spring wheat correlated positively with soil mineral $\mathrm{N}$ content before the growing season. In the present study however, the yield could not be deduced from the soil $\mathrm{N}$ contents, as in general spring barley yields were similar after early and late autumn ploughing. Similar soil N but lower yields after spring incorporation in some cases when compared with late autumn ploughing confirms this conclusion. Tillage treatment obviously affected the other growing conditions so, that the effect of soil mineral $\mathrm{N}$ was masked.

Because decreasing the risk of $\mathrm{N}$ leaching (Haynes 1994, Känkänen et al. 1998), delayed ploughing in autumn is preferable to early autumn ploughing for incorporating a green manure crop. Delayed autumn ploughing is particularly suitable for red clover sown in the spring of the green manure year, giving the clover a longer time to accumulate N; Wivstad (1997) found that the N yield of red clover doubled between the ages of 14 and 20 weeks. In our study cereal yields were better after late ploughed red clover, even in Y1, in which late autumn ploughing otherwise decreased the grain yield of the following 1st year test crop (spring barley).

Changes in mineralization rate of plant biomass are also marked due to changes in chemical composition of the biomass during plant growth (Franzluebbers et. al 1994, Wivstad 1997). In our study, however, this effect was expected to be small as compared with the decrease in mineralization due to lower soil temperatures in late autumn (Anderson 1960).

Soil type and previous crop have to be taken 
Känkänen, H. et al. Timing of plant biomass incorporation: effect on cereal grain yield

into account when considering time of tillage. Generally spring ploughing is not recommended for heavy clay soils (Mikkola 1989). On the other hand, reduced tillage with a cultivator in spring resulted in our study in comparable grain yield with autumn ploughing on heavy clay soil. However, mistiming either the basic tillage or seed bed preparation can lead to a major yield loss. On other soil types tested in our study, spring ploughing decreased the grain yield as compared with autumn ploughing in only one trial, whereas reduced tillage in spring reduced the yield in many cases.

When comparing reduced tillage and ploughing of green manure, Poutala and Hannukkala (1995) found that reduced tillage had an adverse effect on the following grain yield, but Maillard and Vez (1991) found a beneficial effect. In the former study autumn ploughing was compared with reduced tillage of hairy vetch and persian clover in both autumn and in spring in Finland, whereas the latter group compared shallow and deep autumn incorporation of mustard in Switzerland. According to the present study, the reduced tillage of red clover, a perennial strongly competing with cereal crops by regrowth, is particularly unsuitable. Even in the absence of competition, an adverse effect was obvious, reduced tillage in spring being an almost equally poor method for incorporating of both westerwold ryegrass and red clover.

Although $\mathrm{N}$ fertilization of the following crop can compensate the differences caused by precrops (Lindén and Wallgren 1993) or tillage methods (Francis and Knight 1993), the effect of incorporation time was similar at all $\mathrm{N}$ fertilization rates in this study. Thus, timing of incorporation of crop biomass do not depend on the fertilization intensity used in the farming system, but the decisive factor is the amount and content of $\mathrm{N}$ in the biomass.

Because of the variable effects in individual trials during the second after-effect year, neither the timing nor the method of incorporation could be concluded to clearly affect the grain yield of 2nd year test crop, oats. The results suggest, that conventional early autumn ploughing is no more appropriate than any of the other tillage treatments used in this study.

Because of numerous experimental sites and two experimental years, this study covered well the Finnish growing conditions. However, there was variation in results between individual trials caused by anomalous weather conditions. In our opinion this did not cause serious problems in interpretation of the results, even in J1 where the drought severely decreased the yield of spring barley. The main conclusions of this study can be generalized in conditions where soil is frozen during long winter period.

\section{Conclusions}

Our results suggest that autumn ploughing is a more reliable procedure than ploughing or reduced tillage in spring, in efforts to obtain good spring cereal yields under Finnish conditions. Because of no adverse effect on the grain yield of the succeeding spring barley, autumn ploughing should be delayed when incorporating $\mathrm{N}$ rich green manure crops. Also spring ploughing could be used on all but clay soils, although an adverse effect on the grain yield of spring barley was seen even on sandy soil in some cases. Reduced tillage is not recommended for incorporating grasses or perennial legumes in spring.

\section{References}

Anderson, O.E. 1960. The effect of low temperatures on nitrification of ammonia in Cecil sandy loam. Soil Science Society of America Proceedings 24: 286289.
Badaruddin, M. \& Meyer, D.W. 1990. Green-manure legume effects on soil nitrogen, grain yield, and nitrogen nutrition of wheat. Crop Science 30: 819-825.

Clement, A., Ladha, J.K. \& Chalifour, F.P. 1995. Crop 
Vol. 8 (1999): 285-298.

residue effects on nitrogen mineralization, microbial biomass, and rice yield in submerged soils. Soil Science Society of America Journal 59: 1595-1603.

Finnish Meteorological Institute 1991. Climatological statistics in Finland 1961-1990. Supplement to the Meteorological Yearbook of Finland 90, 1: $125 \mathrm{p}$.

Francis, G.S., Haynes, R.J. \& Williams, P.H. 1994. Nitrogen mineralization, nitrate leaching and crop growth after ploughing-in leguminous and non-leguminous grain crop residues. Journal of Agricultural Science 123: 81-87.

- \& Knight, T.L. 1993. Long-term effects of conventional and no-tillage on selected soil properties and crop yields in Canterbury, New Zealand. Soil \& Tillage Research 26: 193-210.

Franzluebbers, K., Weaver, R.W. \& Juo, A.S.R. 1994. Mineralization of labeled $\mathrm{N}$ from cowpea (Vigna unguiculata L. Walp.) plant parts at two growth stages in sandy soil. Plant and Soil 160: 259-266.

Haynes, R.J. 1994. Impact of management practices on nutrient cycling. In: Pankhurst, Doube, Gupta \& Grace (eds.). Soil biota: management of sustainable farming systems. p. 172-181.

Känkänen, H. 1993. Nitrogen in soil and yields of cereals after green fallows. Soil Tillage and Environment. Proceedings of NJF seminar no. 228, Jokioinen, Finland, 8-10 June 1993. p. 260-264.

-, Kangas, A., Mela, T., Nikunen, U., Tuuri, H. \& Vuorinen, M. 1998. Timing incorporation of different green manure crops to minimize the risk of nitrogen leaching. Agricultural and Food Science in Finland 7: 553567.

Kauppila, R. 1983. Palkokasvien käyttö viherlannoituksessa. Summary: Use of legumes in green manuring. In: Biologisen typensidonnan ja ravinnetypen hyväksikäytön projekti. Suomen itsenäisyyden juhlavuoden 1967 rahasto. Julkaisu 6. p. 51-92.

Kirchmann, H. \& Marstorp, H. 1991. Calculation of N mineralization from six green manure legumes under field conditions from autumn to spring. Acta Agriculturae Scandinavica 41: 253-258.

Lemon, R.G., Hons, F.M. \& Saladino, V.A. 1990. Tillage and clover cover crop effects on grain sorghum yield and nitrogen uptake. Journal of Soil and Water Conservation 45: 125-127.

Lindén, B. \& Wallgren, B. 1993. Nitrogen mineralization after leys ploughed in early or late autumn. Swedish Journal of Agricultural Research 23: 77-89.

Maillard, A. \& Vez, A. 1991. Influence du travail du sol sur la valorisation des engrais de ferme et des engrais verts en grandes cultures. Summary: Influence of tillage on nitrogen efficiency of farmyard and green manure under cropland. Revue Suisse d'Agriculture 23, 1: 11-14.

Mikkola, H. 1989. Syyskyntöä korvaavien muokkausmenetelmien vaikutus kevätvehnän satoon 19751988. Summary: Effects of autumn ploughing and different reduced tillage methods on yield and quality of spring wheat 1975-1988. Vakolan tutkimusselostus 54. p. 3-32.

Müller, M.M. \& Sundman, V. 1988. The fate of nitrogen $\left({ }^{15} \mathrm{~N}\right)$ released from different plant materials during decomposition under field conditions. Plant and Soil 105: 133-139.

Poutala, R.T. \& Hannukkala, A. 1995. The effect of the method of incorporation of Trifolium resupinatum $\mathrm{L}$. and Vicia villosa Roth. residues in the soil and the performance of a succeeding cereal crop. Acta Agriculturae Scandinavica, Sect. B, Soil and Plant Science 45: 251-257.

Sanderson, J.B. \& MacLeod J.A. 1994. Soil nitrate profile and response of potatoes to fertilizer $\mathrm{N}$ in relation to time of incorporation of lupin (Lupinus albus). Canadian Journal of Soil Science 74, 2: 241-246.

SAS Institute Inc. 1990. SAS Procedures Guide. Version 6, Third Edition, Cary, NC. 705 p.

- 1991. SAS System for Statistical Graphics. First Edition, Cary, NC. 697 p.

- 1992. SAS Technical Report P-229. SAS/STAT Software: Changes and Enchancements. Release 6.07, Cary, NC. 620 p.

Thorup-Kristensen, K. 1996. Effect of catch crop incorporation time on $\mathrm{N}$ availability for a succeeding crop. In: Schröder, J.J. (ed.). Long Term Reduction of Nitrate Leaching by Cover Crops. First Progress Report of EU Concerted Action (AIR3) 2108. p. 49-54.

Van Schöll, L., Van Dam, A.M. \& Leffelaar, P.A. 1997. Mineralisation of nitrogen from an incorporated catch crop at low temperatures: experiment and simulation. Plant and Soil 188: 211-219.

Vinther, F.P. 1994. N-mineralization and denitrification after incorporation of catch crops and plant residues. The use of catch or cover crops to reduce leaching and erosion. Proceedings of NJF seminar no. 245, Knivsta, Sweden, 3-4 October 1994. p. 105-114.

Wallgren, B. \& Lindén, B. 1991. Residual nitrogen effects of green manure crops and fallow. Swedish Journal of Agricultural Research 21: 67-77.

Wivstad, M. 1997. Plant morphology and content of nitrogen, cell wall and lignin at different phenological stages of red clover and yellow sweetclover. Swedish Journal of Agricultural Research 27: 3-14. 
Känkänen, H. et al. Timing of plant biomass incorporation: effect on cereal grain yield

\title{
SELOSTUS
}

\section{Syyskyntö on luotettava tapa muokata kasvimassa maahan}

\author{
Hannu Känkänen, Arjo Kangas, Timo Mela, Unto Nikunen, Hannu Tuuri ja Martti Vuorinen \\ Maatalouden tutkimuskeskus
}

Huoli viherlannoitustypen kohtalosta maahan muokkaamisen jälkeen synnytti tarpeen selvittää sopivinta muokkaamisen ajankohtaa. Vaikka maan typpimääritykset antavatkin käsityksen muokkausajankohdan suorasta vaikutuksesta huuhtoutumisriskiin, vasta seuraavat kasvukaudet täydentävät tiedon ajoituksen onnistumisesta. Pieni seuraavan kasvin sato lisää välillisesti ravinteiden huuhtoutumisriskiä, koska ravinteiden ottaminen maasta on vähäisempää suuren sadon tuottavaan kasviin verrattuna. Kahdesta typen huuhtoutumisriskiä vähentävästä muokkausajankohdasta tulee viljelyn kannattavuuden vuoksi valita se, joka antaa paremman satovaikutuksen.

Tutkimus perustuu viherkesantovaihtoehtoihin tavanomaisessa viljanviljelyssä. Aiempien tutkimustulosten osoitettua viherlannoitteen muokkausajankohdan vaikuttavan typen huuhtoutumiseen ja hyväksikäyttöön yleensä, haettiin tässä tutkimuksessa parhaita ajankohtia typpipitoisuuksiltaan erilaisten kasvustojen muokkaamiseen.

Seitsemässä kokeessa Maatalouden tutkimuskeskuksen neljällä tutkimusasemalla yksivuotisena viherkesantona kasvaneet ruisvirna, puna-apila ja westerwoldin raiheinä sekä tuleentuneena korjatun ohran sänki ja puintijäte kynnettiin maahan joko aikaisin tai myöhään syksyllä (vaihdellen syyskuun alusta marraskuun alkuun) tai keväällä ennen kylvömuokkausta. Kyntöjen vaihtoehtona kasvustot muokattiin maa- han myös kyntämättä keväällä ennen varsinaista kylvömuokkausta.

Syyskynnöt johtivat hyvään seuraavaan ohrasatoon luotettavammin kuin kevätkyntö tai kevennetty muokkaus keväällä. Kevätkyntöä voidaan kuitenkin käyttää typen huuhtoutumisen välttämiseksi lukuun ottamatta savimaita, joilla se selkeästi pienensi ohran jyväsatoa. Erityisesti raiheinän ja puna-apilan kevennetty muokkaaminen maahan keväällä pienensi usein samana keväänä kylvetyn ohran jyväsatoa. Muokkauksen vaikutus kauran jyväsatoon toisena kasvukautena muokkausten jälkeen vaihteli, eikä mitään muokkausmenetelmää voida sen perusteella pitää muita parempana.

Aikaisemmin julkaistussa, maan mineraalitypen määriä selvittäneessä tutkimuksen osassa päädyttiin suosittelemaan kynnön viivyttämistä typen huuhtoutumisen vähentämiseksi. Jyväsatojen perusteella syyskynnön viivyttäminen ei vaaranna viljelyn kannattavuutta. Lokakuun olosuhteita tulee kuitenkin seurata, jotta vältetään maan rakenteen vaurioittaminen kyntämällä liian märissä oloissa. Kokeissa kasvustolliset ruudut olivat syksyllä kynnettäessä selkeästi kuivempia kuin sängellä olevat. Kun muokkausajankohdan vaikutus maan mineraalitypen määrään oli lisäksi pieni viljan jälkeen ja kasvoi viherkesannon typpipitoisuuden kasvaessa, kannattaa maatilan syyskynnöt aloittaa sängiltä ja päättää typpipitoisimpiin viherkesantoihin. 